DE DE GRUYTER

OPEN

DOI: 10.1515/jolace-2016-0009

\title{
Foreign language education of seniors
}

\author{
Ctibor Határ \& Soňa Grofč́́ková \\ Constantine the Philosopher University in Nitra, Slovakia \\ chatar@ukf.sk
}

\begin{abstract}
This study is of a theoretical-conceptual nature and is a partial outcome of the research project VEGA MŠVVaŠ SR and SAV no. 1/0176/15. It deals with one of the problems currently faced by educational theory and practice, i.e. the foreign language education of seniors. The trend is typical for many EU member states, since it results from the needs of a modern society. In addition to strategic documents, programs and legislation which binds the Slovak Republic to create conditions for lifelong education, including foreign language education, the authors are more closely preoccupied with specificities and possibilities of the language education of seniors, which are explained on a comparative basis with the language education of children and youth. Even though in literature one can find results of many substantial empirical research projects devoted to foreign language education of children and youth, research into the education of adults and seniors in the area of foreign languages falls behind considerably. A sufficient platform for the methodology of language education of adults and seniors in Slovakia has not been created either, if compared with the methodology of language education of younger age categories. This shortcoming is often quite noticeable in practice. The study attempts to pay adequate attention to the analysis of selected teaching styles specific for adult and senior age as well as teaching methods which may be used in the language education of seniors.

\section{Keywords}

senior, foreign language education, starting points, specificities, possibilities and institutional background of foreign language education of seniors, teaching styles of seniors, methodological approaches to foreign language education of seniors, language pedagogy; geragogics
\end{abstract}

\section{Introduction}

Recently at various levels of social life there has been much discussion on the need or rather a capability of a human being to communicate through speaking and writing, not only in one's mother tongue, but in a foreign one as well, potentially in several foreign languages. This usually applies to the persons in pre-productive and productive age who are either using a foreign language or will be using it especially in their jobs. Nowadays it is not an exception also for the individuals who have already finished their professional activity and set on a journey of active and productive old age. ${ }^{1}$ Education of seniors not only has become a topic of the day, acquiring ever greater popularity, but also an important element, if not a means, of the building of knowledge-based society. Institutions, organisations as well as various subjects of the third sector have enlarged their offer of educational programs and courses devoted specifically to seniors. Out of all the offered educational programs, language and ICT courses have become relatively most preferred. Moreover, the educational practice has shown that not all the subjects offering language courses for seniors are adequately prepared as regards teaching staff (i.e. qualifications of foreign language teachers). Many times the courses were taught by the elementary and secondary school teachers who applied methodology of work with children also in their work with

1 For more on individual concepts of ageing, see Repková (2012). 
seniors, which was counterproductive. As a participant of lifelong education in the area of foreign languages, a senior enters the educational process with certain expectations, especially educational needs which can be adequately saturated by the knowledge of a foreign language.

\section{Legislative, programmatic and documentary starting points in the foreign language education of seniors}

The need of lifelong education, which should objectively stretch up to the old age, has been intensively discussed for a few years, mostly because of the population's growing older. As a response one could see codification of various supporting, opinion making as well as binding documents, programs and laws in which the idea of lifelong education, including foreign language education, became of key importance. Many of these programs and documents were created on the basis of international resolutions. Out of them, we have chosen the following programs, laws and documents dealing with the issue.

The National Program for the Protection of Elderly People (Národný program ochrany starších l'udí) has declared in the area of education, among other things, also the necessity to pay increased attention to the universities of the third age, to support the increasing in the number of participants in further education and the creation of (new) educational programs at the universities of third age, in order to preserve and support spiritual health and make processes of ageing easier. It is undeniable that language education is one of the frequently searched for educational programs at the third age universities.

Memorandum on Lifelong Education (Memorandum o celoživotnom vzdelávaní sa) penetrates into the essence of lifelong education through its six key messages ${ }^{2}$. The first message speaks about new basic skills for all. They are the skills which are necessary for an active participation in the life of knowledgebased society and economy. The Memorandum (2000, p. 12) includes command of foreign languages to the skills as well.

In 2002 the Government of the SR introduced the National Program of Education in the Slovak Republic (Národný program výchovy a vzdelávania v Slovenskej republike) which included to lifelong education also the socio-cultural, civic, and spare time education, including the seniors. The National Program recommends, among other things, creating a lifelong education system for the acquisition and improvement of language competencies.

In 2007 the European Union issued a document Key Competencies for Lifelong Learning - European Framework of Reference (Kl'účové kompetencie pre celoživotné vzdelávanie - európsky referenčný rámec) as an enclosure to the Recommendation of the European Parliament and of the Council of 18 December 2006 on key competences for lifelong learning. The given framework of reference describes in more detail 8 key competences ${ }^{3}$. Communication in foreign languages is based on basic skills which "consist of the ability to understand spoken messages, to initiate, sustain and conclude conversations and to read, understand and produce texts appropriate to the individual's needs. Individuals should also be able to use aids appropriately, and learn languages also informally as part of lifelong learning" (Klúčové kompetencie..., p. 5).

Another significant document is the Strategy of Lifelong Learning and Lifelong Counselling to 2015 (Stratégia celoživotného vzdelávania a celoživotného poradenstva do roku 2015), whose primary mission was to form a society based on knowledge by means of all systems and cycles of education. Not all the

2 It includes the following key messages: new basic skills for all, more investment to human resources, innovations in education, assessment of education, new approach to vocational orientation and consulting, drawing education closer to homes (Memorandum on Lifelong Education, p. 2).

3 It includes the following competencies: communication in mother tongue, communication in foreign languages, mathematical competence and basic competencies in research and development, digital competence, learn to teach, social and civic competencies, leadership and entrepreneurship, cultural awareness and expression (Key Competencies for Lifelong Learning - European Framework of Reference, p. 3). 
priorities of this Strategy have been fulfilled, some of them have not even been begun, says the prologue of the new Strategy of Lifelong Learning 2011 (Stratégie celoživotného vzdelávania 2011). It considers the need to develop key competences one of its problem areas, to which the expert group included communication in world languages, digital literacy, business competences, active citizenship and financial literacy. The basic principle for the selection of these competencies was to understand education not only as an instrument of fulfilling the needs of professional development, but also as an instrument of the development of the personality of human being in order to be successful in society and develop his/her personal interests (Strategy of Lifelong Learning 2011, p. 26).

Law no. 568/2009 on Lifelong Learning (Zákon č. 568/2009 Z. z. o celoživotnom vzdelávaní v znení neskorších predpisov) puts lifelong learning on two pillars, i.e. on school education and on further education. The kinds of further education include spare-time education, civic education, education of seniors, and other education, through which the participant in education saturates his/her interests, gets involved in the life of civil society and develops his/her personality (§ 4, section 1, letter d) of the law). The Law also includes language schools among institutions of further education.

The year 2013 saw the origin of three significant documents, that is, Strategy of Active Ageing (Stratégia aktívneho starnutia), Action Plan for the Fulfilling of the Strategy of Active Ageing (Akčný plán napÍñania stratégie aktívneho starnutia) and National Program of Active Ageing for 2014 - 2020 (Národný program aktívneho starnutia na roky 2014 - 2020) in which the idea of active ageing was fully established and substituted current approach to seniors as subjects of protection (Bútorová et al., 2013). The National Program of Active Ageing lists six objectives within lifelong learning (Objective 1: In order to increase the quality of life it is necessary to create new and develop the existing opportunities for the education of people in a higher age, to support their active life and improve their chances at labour market. Objective 2: To legislatively anchor individual kinds and forms in the education of the elderly into the educational system of the Slovak Republic. Objective 3: To financially secure individual kinds and forms in the education of the elderly. Objective 4: To improve digital literacy of elderly people. Objective 5: To implement programs for the improvement of financial literacy of elderly people. Objective 6: To strengthen and systematically develop the quality of specific professional career advisors for work with elderly people; c.f. Národný program aktívneho starnutia na roky $2014-2020$, p. 32-35), which in themselves carry a mission of creating certain fundament of our work. ${ }^{4}$

Even though one can say, based on the above, that during the entire human life, thus also in old age, language education has a strong program-legislative platform, its concrete application in practice has still considerable shortcomings.

\section{Specificities, possibilities and institutional background of foreign language education of seniors}

Literature as well as educational practice often ignore the need to differentiate between the (foreign language) education of youth on one hand and the (foreign language) education of adults and seniors on the other hand. There is no doubt that there are significant differences between them, especially with regard to motivation, methodology itself, and partly also the content of foreign language education. While for children and youth motivation to study foreign languages comes, as a rule, from the outside (e.g. a grade as a motivational factor), in case of adults and seniors one may rather speak about inner motivation. A senior learns a foreign language not to be dependent on others communicating in a foreign language, family members, friends or acquaintances, to prove to others, usually the younger ones, that he/she is also able to progress..., or just to be able to meet his/her peers in language courses.

\footnotetext{
4 To preserve the cohesion of the text, all electronic sources for the mentioned documents, programs and law are provided in References.
} 
The study saturates rather social than educational needs ${ }^{5}$ of a senior. Prusáková (2010, p. 25) claims that in analysing educational needs it is important to know a possible motivation and to differentiate the need to deal with a concrete situation from educational need. While in case of the need to deal with a concrete situation the starting point is the fact that one does not have enough knowledge and cannot solve the situation (insufficient knowledge and skills), with the need to educate oneself the leitmotif is getting education in order to come to terms with changing living conditions. In practice it means that education of seniors in foreign languages may be understood either as a process of saturating a senior's needs or as the need in itself (Prusáková, 2010). Getting to the curricular area, content of education (we do not mean grammar, sentence constructions, vocabulary, etc., but rather thematic orientation of the used teaching texts) changes with participants' age. It is logical that in language education of seniors we will not use materials for children and youth, which was not a rule in the past, that are often filled with slang expressions, time and age related picture material as well as various extra textual components which may have a disturbing effect on seniors. ${ }^{6}$ As far as methodological aspect is concerned, a very important role is played by a chosen methodological approach which should fully respect the individual, especially age specificities of participants in education. Based on the Berlin study, Mitterlechner (2012, p. 9) claims that in work with seniors it has to be taken into account that:

- "learning takes longer for older people,

- they are more sensitive to external disturbances,

- they put emphasis on the meaning of education,

- educational content must be relevant for learners, i.e. it has to be meaningful and it must bring benefit,

- success in learning depends on motivation,

- continuation with what was previously learned (connection to the knowledge acquired earlier) has a favourable effect,

- learning is dependent on social factors,

- unused learning capacities are available in older age as well".

While in the work with contemporary seniors grammar-translation method is in the centre of attention, which more or less respects their way of acquiring, preserving and using a foreign language, the work with contemporary children and youth is rather characteristic for the changing of several procedures within one teaching unit, with emphasis placed on the use of audiolingual and communicative methods. ${ }^{7}$ We would argue that neither the preferred interests, nor methodology of foreign language education, which suits contemporary seniors, will meet the needs of those seniors who will then be taking language courses, since contemporary seniors grew up in a different social system which is also manifested in their interests, expectations and preferred methods. Not only the age, but also requirements, interests and entire views of life change from generation to generation, or from year to year.

Petřková and Čornaničová (2004, p. 69) mention also potential barriers resulting from subjective (e.g. fear of the decrease of sensory and cognitive capabilities, low self-confidence, stage-fright and

5 Průcha (2014: 36-37) distinguishes three kinds of educational needs, i.e. educational needs of individuals (the needs of real or potential participants of education that are variable - depending on age, sex, educational level, etc.), educational needs of groups of subjects (age, professional, socioeconomic, ethnic and other groups), and educational needs of enterprises, sectors of national economy, entire society (including, especially, requirements of employers transformed to the needs, and, at a national level, national priorities /objectives of education).

${ }^{6}$ A comparison of the pedagogic and andragogic approach, or education of children and adults in general, is (was) more closely analysed by several authors, such as Knowles, Jarvis, Matulčík, and others.

7 Methodological procedures, even though mostly with focus on the target group of children and youth, are more closely discussed by foreign language methodologists, in our country for example Pokrivčáková, Tandlichová, Horváthová, Hockicková, Straková, Lojová and others. 
anxiety from new situations, shortage of vitality, indecisiveness, etc.) as well as objective (e.g. shortage of information about educational possibilities or bad approach to them, unsuitable time of education, problems with transport, financial problems, etc.) conditions which can slow down not only the learning. Many of the given educational barriers are not associated with the children's or youth age, and therefore it is necessary to have lecturers or teachers specifically trained for foreign language education of seniors.

Drawing on the definition of education (for more, see Švec, 2008), the following three possibilities of foreign language education of seniors can be distinguished:

1. at the level of formal education - this may include the study of foreign languages at elementary, secondary schools and higher educational institutions; the result of this is the obtaining of respective level of formal education aimed at a given foreign language (this possibility is more specific for children, youth and adults in productive age);8

2. at the level of nonformal education - this may include the study of foreign languages at language schools or within educational language programs/courses at universities of the third age, academies of the third age, in daily centres (former pensioners' clubs), and elsewhere;

3. at the level of informal education - this is mostly spontaneous and non-institutional education in foreign languages, e.g. through communication in foreign language environment, watching TV programs or listening to radio broadcasting in a foreign language, reading books, promotional materials or tourist guides, etc.

As indicated above, the strongest institutional base of foreign language education of seniors under our conditions is created by language schools and universities of the third age. Law no. 245/2008 Coll. on Education incorporates language schools into the system of schools. According to $\S 53$ of the Law language schools provide language education in foreign languages based on specific educational plan, then organise teaching foreign languages for specific purposes, and, at the same time, prepare students for translation and interpreting. Education is provided in courses. Its target group is made up, according to the Law, by elementary and secondary school pupils, college and university students and adults (including seniors - noted by the authors). Another educational subject providing (informal) spare-time education for elderly people and seniors (not only) in foreign languages is the university of the third age. The study is carried out in accordance with the conception of lifelong learning in the Slovak Republic, as a continuation of the gerontological program of UNESCO (5/2011 Statute of the University of the Third Age). As far as the organisation of work with seniors is concerned, the following two basic approaches can be distinguished (whose combination is not excluded): classical academic approach, emphasising especially the intellectual activity of participants, and traditional educational approach, putting emphasis especially on mass events with a high number of participants (Čornaničová, 1998). In western countries, e.g. in Germany, integrational model of the study of seniors at universities of the third age has been widely used. Its essence lies in seniors' participating in educational events together with full-time students. A more characteristic model for the Slovak Republic is the segregated education model in which the senior and full-time students study separately. In addition to the mentioned institutions and seniors living in their natural home environment, language education may also be provided to the institutional seniors from social services facilities. In 2013 we carried out a research with a sample of 259 respondents consisting of the clients of facilities for seniors from seven Slovak regions. It was found out, among other things, that the interest in foreign language courses was expressed just by $7(2.70 \%)$ clients (Határ, 2014b). This may be justified mainly by the nature of the institution which provides primarily social services, not education, by the specificity of the target group, consisting of the seniors depending on care, changing needs of ageing and old people, their abilities,

8 Individual stages of language education are discussed in detail by Law no. 245/2008 Coll. On Education in $\S 17$, par. 3. 
previous and current social status, their former profession, personal and other barriers, inner and outer motivation, etc.

The focus of our study is thus on the organised and intentional foreign language education of noninstitutionalised seniors, in particular on the study of German or English as the first foreign language, at the level of informal education (language schools or universities of the third age).

\section{Analysis of the selected learning styles of seniors}

In addition to the age specificities and the above mentioned factors, a teacher or a lecturer must be aware of the fact that a group as a whole is composed of various personalities who are different in many respects, and they have to be approached on an individual basis and, at the same time, as a group. Therefore, we have concentrated on the educational-psychological construct, i.e. a participant's learning style. The aim of this study is neither to explain the concept of learning or cognitive style and the difference between these categories, nor to discuss the adequacy or validity of the measuring of learning style. We are aware of the fact that there is a great number of theories explaining learning styles from various aspects. In identifying and classifying learning styles one may draw on the combination of three aspects:

1. How a person primarily accepts information as simply as possible through the senses, how he/she learns about the surrounding world. Sensual perception is understood as biologically conditioned reactions to external environment through which we efficiently adjust and process information.

2. The way information is organised and processed points to the process of thinking and remembering. Also in this process a learner gives preference to a way through which he/she "captures" the information, speaking, in this case, about abstract concepts and generalisation or concrete examples. Then the information is arranged either through logical, sequential ways (step by step we build a picture) or holistically (first a picture is built, then details).

3. What conditions are necessary to organise information and present new knowledge to others (e.g. emotional, social, physical environment). New information may be organised in a holistic way or through a detailed analysis. Presenting is either verbal or written (use of pictures) (Petty, 2002).

Based on this classification, we may look at individual theories dealing with learning styles, applying them to the adult and senior age. Seniors as a specific group of learners have their own learning procedures and strategies which serve them well in other contexts. They can be used in language education as well. A lecturer should therefore be sufficiently flexible to allow various approaches to the tasks in the course (respecting learning styles).

In acquiring information, understanding, in general learning, one connects various senses, some of them more preferable than others. A significant factor in every learning is undoubtedly health, since many deficits, chronical diseases, may influence seniors' ability to learn. The loss or weakening of hearing influences the ability to understand speech, especially when it is at the same time accompanied by a noise, or sounds in the background. Sharpness of sight also gets worse with ageing. Worse motion, loss of teeth and other defects or restrictions (naturally, these problems cannot be associated only with seniors) will be influencing the preference of a certain sensual channel. In foreign language teaching there is an approach called neuro-linguistic programming, described by the acronym VAKOG (visual, auditory, kinaesthetic, olfactory and gustatory type). Based on the way of perception and reaction to learning style, four methods of learning are distinguished; one of the most common typologies is $\mathrm{N}$. Fleming's VARK in which every letter denotes one learning style - visual, aural, read/write, kinaesthetic. Sensual preferences are created through positive experience. Every learner uses a net of neurons which deal with the problem in a simplest and fastest way. If a learner further uses these neuron connections, they become stronger. So, for example, if an audial learner acquires positive result in listening and dialogue, he/she will continue in such learning, it will become its preference, and this procedure will be strengthened by the use of a given sensual organ. 
- Visual type learner needs a mental model which he/she can see, a structure to express meaning, since he/she has a difficulty to understand verbal instructions. The learner can have a problem to remember names, but remembers details. He/she enjoys books, is fond of reading them (mostly alone, not indirectly), as well as pictures, graphs, tables, posters; he/she should be using visual organisers (e. g. conceptual maps, posters). Such learner organises ideas by writing them down, likes jigsaws, notices small details, prefers when a lecturer keeps eye contact. This type should be making notes from what he/she hears at a lesson and the tasks assigned by the teacher to better remember the information.

- Audial type learner likes explication, lectures, the information which would make a meaning for him/her, discussions about content, not just listening and making notes. He/she likes discussions with others, but also with oneself, often moving lips during reading, talking to oneself. This type searches for opportunities to verbalise ideas. Such learners like activities during which they can talk to other participants, express opinions, being able to remember easily and being also characteristic for their weak coordination of fine motoric skills. They learn well when accompanied by others and through conversation with the lecturer.

- Verbal (R) type learner was included into the characteristics of former types due to the need to communicate the seen and the heard.

- Kinaesthetic (K) type learner feels best to learn through the movement and manipulation with objects. The type wants to feel, either through touching, smelling or tasting. It is suitable to create such situations for this learner during which he/she may move, change a workgroup, perform activities, create manually, since these activities are helpful in understanding the content, usually having good motoric skills. Therefore, it is recommended using music, arts, manipulation with objects, simulations, roleplays, cooperative teaching, activities distributed to small blocks. The learner learns best through experience (c.f. Tileston, 2004).

Another typology of adult learning styles is offered by Willing (in Harmer, 2007, p. 88) who specifies 4 learner categories.

- Converger type prefers individual work, avoids group activities, is independent and has sufficient faith in his/her own abilities. It is an analytical type, introducing one's own structures in learning and having a tendency to be calm and pragmatic.

- Conformist type emphasises "learning about language" at the expense of learning for a use. The type has a tendency to be dependent on authorities, enjoying work in non-communicative groups fulfilling the orders, and preferring to have a well organised teacher setting a direction in the group.

- Concrete type is like the conformist, but appreciates a social type of learning from one's own experience. The learner is more interested in the using of language and communication than in language as a system, enjoying plays and work in a group.

- Communicative type is focused on the use of language, feeling oneself comfortably outside the classroom and being able to show a level of self-confidence and an ability to risk. This learner is more interested in social interaction with people speaking foreign language than in the analysis of how a given language works. He/she likes working without teacher guidance.

Experiential psychology considers learning a cyclic process based on experience (dependent on age). Kolb explains the theory of a cycle by claiming that man lives through concrete experience, perceives it, observes and thinks about it. The result of thinking is the creation of abstract concepts and generalisations with which he/she experiments. The learner actively uses in practice conclusions and concepts leading to a new, enriched experience. The author created a model through a combination of ways of information acquisition (concrete and abstract thinking) and ways of information processing (reflective observation and active experimentation). The following styles are defined: 
- accommodating (dynamic), with the learner thinking concretely, actively processing information, needing experimentation and flexibility in tasks which are a challenge. He/she is intuitive, searching for opportunities and objectives, pragmatic, spontaneous, sociable, good organiser, non-systematic, impulsive;

- diverging (innovatory), with the learner thinking concretely, processing information reflectively (contemplatively), needing to be personally involved in the learning activity. He/she has imagination, is emphatic, intuitive, flexible, emotional, sociable, enjoying exploration, generating ideas, being non-systematic, spontaneous;

- assimilating (analytical), with the learner thinking abstractly, processing information actively, needing pragmatic, problem learning activities. He/she is analytical, logical, systematic, good organiser, enjoying theorising and concrete tasks, but, as a student, being rather passive;

- converging (practical), with the learner thinking abstractly, processing information reflectively (contemplatively), requiring detailed work, step by step. He/she is decisive, pragmatic, rational, analytical, systematic, theoretical, focused on tasks, with one-sided thinking, without imagination, and with lower intuition (in Riding \& Rayner, 2009).

Another theory which can be used with seniors learning a foreign language is their differentiation on the basis of mental abilities. According to Švec (2002), ability is a quality of an individual, defined as a prerequisite quality of social individualities to be, and thus to understand, evaluate, act, make oneself understood and understand. Gardner (1983) sees intelligence as an ability to deal with problems and create valuable products in one or several cultures. Human abilities are characterised through the theory of multiple intelligence, which means that man has independent systems of various kinds of abilities, independent on one another. Intelligence is thus a combination of various abilities of whom each has a meaning for life. Each person has all kinds of them, some more or less developed, differing just in the strength and way of functioning. Individual intelligences get activated when one responds to various kinds of stimuli and information. Drawing on this, the following learning styles were distinguished:

- Linguistic style is activated during speaking, listening, reading and writing words.

- Logical-mathematical style works during problem solving, new solutions, understanding abstract models, connections, relations.

- Spatial-visual style is activated during the presentation of unusual, colourful pictures, when imagining something, during the manipulation with images in mind, during orientation in an unknown environment.

- Kinaesthetic style works with bodily movements of all kinds, when expressing content with body, during dramatization, when touching objects.

- Musical style is activated by sound resonance, vibrations, music.

- Interpersonal style is initiated during work and communication with other people, when there is a need to understand and comprehend them.

- Intrapersonal style is initiated during self-reflection, introspection, metacognition (Gardner, 1983).

Tanner (in Harmer, 2007) proposes activities for the development of individual language skills, grammar, vocabulary and literature, taking into account individual types of intelligence.

Nowadays there are also other theories drawing on research into human brain. The explanation of thinking is closely related to brain activity. Both hemispheres work simultaneously, but which area is activated during thinking depends on the object (content) of thinking. The hemispheres have different roles during thinking. Functional differences lie in the fact, for example, that the right hemisphere concentrates on intuition, creativity, spatial information, and the left one is analytical, logical, verbal, rational. Thinking thus requires coordination of many brain areas, and the way of thinking also depends on which of the hemispheres is more active. Conscious thinking is what we are aware of at a given 
moment, and therefore it is significantly limited, is structured through cause and effect, has a tendency towards the logic and consecutiveness of information processing. On the other side, unconscious thinking is permanently running in the background of conscious thinking, and by this determines most of our behaviour, being characteristic for its intuitive nature, speed, creation of associations among various pieces of information (Winston, 2005). Analysing learning, Torrance (in Turek, 2003) draws on to what extent man during learning prefers the right or left hemisphere, since bot concentrate on other types of activity. Based on this preference, cognitive styles are distinguished as well (which are perceived as a permanent aspect of personality):

- The right brain hemisphere reacts emotionally to external situations, interprets nonverbal behaviour of others, produces humour, allows interpretation, with creativity in a forefront, intuition, divergent thinking, putting emphasis on play, fantasy, experience, colours, etc. The activities in the right hemisphere fall to the area of creativity.

- The left brain hemisphere distinguishes sense of words, produces logical thinking, objectively processes new information, emphasises abstract thinking, systematic solution of problems, convergent thinking, rationality, analysis, etc. Intellectual activities in the left hemisphere fall to the area of intelligence (in Turek, 2003).

Research carried out in foreign language education (Krashen, Seliger, Hartnett, Stevick) showed that learners with the dominance of the left hemisphere prefer a deductive style of teaching, while learners with the orientation on the right hemisphere were more successful in an environment with inductive teaching methods. Dominance of the left hemisphere leads to a better production of independent words, to the accumulation of language specificities, to dealing with abstraction, classification, labelling, reorganization. On the other side, dominance of the right hemisphere in thinking leads to a better coping with entire ideas, concepts, generalization, metaphors, with emotional reactions and artistic expressions (Brown, 1987).

The last of the many theories to be mentioned as regards language education and adult learners is the theory based on perception styles (falling to the area of cognitive styles), which are either nondependent on the field of perception or dependent on the field of perception. This quality of (non)dependence on the field of perception becomes more significant with getting older.

- Dependence on perception field is a tendency to be dependent on the entire field which is perceived as a unified whole, with parts within the field not paid attention to. People with the preference of dependence on perception field are more socialized, empathic, sensitive to feelings and ideas of others. In foreign language courses they are more successful in communication activities, prefer analytical methods, put emphasis on details, manage exercises, drilling and other targeted activities. This style significantly positively correlates with success in a language course and is more suitable with inductive methods.

- Non-dependence on perception field allows to distinguish parts of a whole, concentrate only on a part, analyse independently variables without intervention of other, neighbouring variables. Too much dependence on perception field causes that a person sees only parts, not their relation to the whole. The learners with a tendency of non-dependence on perception field are, in general, independent, competitive, self-confident. In foreign language learning, they are doing better with deductive methods (in Brown, 1987).

If a lecturer wants to make foreign language acquisition and learning for seniors easier, there is definitely much sense in taking into account specific features of individual learning styles based on a selected theory. Learning style diagnostics may be carried out through authorized questionnaires, observation, participant's reflexive diary (in case of long-term courses). The knowledge acquired in this way helps the lecturer better design learning activities, select suitable teaching methods, strategies covering the needs of an individual as well as of a group. 


\section{Methods in foreign language education of seniors}

In literature, there is a term named special speech register, with regard to our theme also called "elderspeak", which leads to a communication partner's tendency to adapt to language abilities of seniors, or seniors' speech. It can be usually characterised by a slower production, simplified syntax, avoidance of complicated words, or exaggerated prosody (Coulmas, 2013), which, however, does not have to be a rule. This problem can be similarly perceived in foreign language education as well.

Despite the generally accepted stereotypes, seniors may become good foreign language learners. Difficulties they face in a language course may be overcome especially by the elimination of affective barriers (mostly fear), adaptation of learning environment, preparation of relevant teaching materials, and, naturally, application of effective teaching methods strengthening learning styles and strategies of seniors. The studies on ageing prove that the ability to learn does not decline by age. If a senior is healthy, his/her intellectual abilities do not diminish (Schleppegrell, 1987). According to Cimermanová (2000, p. 25), after taking into account psychological knowledge concerning the relation between age and abilities, an adult should have more advantages in learning a foreign language than a child. A more important factor is the senior's experience with learning at a higher age. If he/she intentionally did not develop individual cognitive processes during productive age (or several years), the acquisition of a foreign language at a senior age may be problematic and demanding.

There are various approaches regarding foreign language education of adults and seniors, but no elaborated methodology of teaching. It is evident that no strategy or method is universal and for all. Each approach has its pros as well as cons.

As mentioned above, adults and seniors often prefer the grammar-translation method, which results from the fact that there is a relation between the level of a foreign language command without accent and the age. The younger a person, the higher level and quality of the sound form of speech (conditioned by an intensive, long term influence of a foreign language environment). A specific accent in the pronunciation of adults is explained by biological determinants, i.e. by the fossilisation of articulators after puberty (Malíková, 2000). Also Tkáčiková (2000) points to the fact that adults manage to learn vocabulary and grammar structure relatively easily, but the sound system of a given language and pronunciation poses problems. Drilling pronunciation, sound production, rhythm, or intonation are considered irreplaceable parts of learning for adult beginners, in order to overcome the fear and frustration from oral production. On the contrary, Schleppegrell (1987), for example, considers drills, the remembering based on short term memory, to be discriminating for seniors, therefore the audiolingual method is not recommended for older adults. The receptive communication skills, such as reading and listening comprehension, may be acquired to a certain extent also outside a foreign language environment. Adults have built habits, experience, and often need to understand the essence of a fact, phenomenon, to see logic in it, to understand relationships, therefore deductive procedures used in explaining gramma suit them. The use of a native language as a communication language is perceived very positively by beginners, since they have just minimum experience with a new language. Therefore, the grammar-translation method is a very frequently used method in adult and senior education.

The use of audiolingual method in a senior age depends very much on knowing the learners group, especially their needs, expectations, as well as health handicaps. It is their previous experience with a certain learning style and methodological procedures what causes them problems with the acceptance of new, maybe less conformal techniques and methods. They are more critical of the selection of methods, which can cause problems in learning. However, audiolingual method in combination with other procedures may be efficient for seniors as well. The emphasis on listening, pronunciation and speech production, e.g. by revision, drilling, leads to the acquisition of fluency and overcoming of the first barrier (e.g. fear); it can lead to the freeing and gradual development of communication skills as well. Cimermanová (2000) has pointed to the fact that adults may repeat and remember longer sequences of sound, syllables, words. They have an advantage in remembering models, or entire 
dialogues. Naturally, recordings and videos must be clear, without noises in the background, with content interesting for a given age category. This method is based on a direct correction of mistakes, which should be, however, reduced in case of seniors, since it could have a de-motivating effect.

The communicative method can be applied in case of seniors with better language skills. Irrespective of the age, the ability to communicate in a foreign language is one of the primary objectives of foreign language education. It is important to support the senior's motivation, the need to express his/her ideas, opinions, either by spoken or written word. The method's advantage lies in the fact that the lecturer corrects only serious mistakes, tempo of speech production is left for the senior, materials are based on inductive procedures, they are heterogeneous and allow for the use of several techniques (e.g. roleplays, picture stories). Adults integrate new content to the already existing cognitive structures, their experience being in this case an advantage. This method may saturate also the social needs of a senior. Providing opportunities to work in pairs, groups, together (but not on a competitive basis), may build self-confidence and support language learning.

The direct method, like the preceding one, is suitable in case of a more advanced language level of seniors. It is based especially on inductive procedures, when the lecturer uses a foreign language during the whole lesson and explains, demonstrates, grammar through pictures, life and institutions, examples (using only a foreign language may be, naturally, modified with regard to seniors). New vocabulary (it is emphasized) is learned in context and directly applied during a lesson. Since the method assumes combination of basic language skills (listening, writing, reading, speaking), it can be called a complex method, which is another advantage as far as the adult and senior age is concerned. It is very successful for learners with inner motivation and for the ones who consider grammar of a key importance in foreign language acquisition. The direct and communicative methods are very similar, differing in several techniques, but the principle is the concentration especially on communication and the use of language.

There are also other methods in foreign language teaching, such as natural method, total physical response, silent way, suggestopedia and other ones (for more see Brown, 1987; Harmer, 2007; Krashen, 1982), which, however, are not in their essence fully adequate for senior age. The selection of methods is dependent on many determinants; first of all, the lecturer must know the needs, motivation, aims, age as well as individual specificities of the group, in order to decide for a correct choice of methods. There is not just one suitable method, since it is the methodological shift and ability to combine methodological procedures which testify to the quality of the lecturer's didactic work.

\section{Conclusion}

The foreign language education of adults in productive age, and particularly seniors, has, alongside its practical social sense, also a potential to become subject of further, even international language pedagogy and geragogic research. There is a need of further research not only into what or who influences current seniors in their determination to study a foreign language, what satisfaction the study gives them, but especially into the efficiency of didactic procedures used in foreign language education. Naturally, the repertoire of research problems depends on several variables which will become subject of further extended exploration (e. g. teaching foreign language as the first or second foreign language, influence of the achieved education and previous experience with language education on the motivation to get further education, influence of bilingual environment, personality factors, influence of health handicap, and many other ones).

In old age the pressure to adapt to social norms is weakened. Social reasons which could influence changes of the preferences in language abilities of seniors have not been paid enough attention to in research. The speech of seniors has been scholarly explored a priori in connection with a disease or impairment (e.g. Alzheimer's disease, aphasia, hearing impairment, etc.) (Coulmas, 2013). Since several research problems of current language pedagogy theory and practice are of an interdisciplinary nature, it is almost necessary to approach them from several aspects, or rather holistically. As far as the theme 
discussed in this paper is concerned, a research team should consist not only of foreign language methodologists, but experts in psychology and andragogy as well.

This paper is submitted to the scholarly community with an expectation that it will initiate a constructive discussion, and thus contribute to a more progressive exploration of the education of seniors in the area of foreign languages.

\section{References}

BERNDT, A. (2000). Senioren lernen Deutsch: 13 Grundgedanken. GFL Journal, 1(3), 1-14. Available at: http://www.gfl-journal.de/3-2000/berndt.pdf

BROWN, D. (1987). Principles of Language Learning and Teaching. NJ: Prentice - Hall.

BÚTOROVÁ, Z. et al. (2013). Śtvrtý rozmer tretieho veku. Desat' kapitol o aktívnom starnutí. Bratislava: Inštitút pre verejné otázky.

CIMERMANOVÁ, I. (2000). Vek, výber metódy a úloha učitel’a. In Pongó, Š. \& Pokrivčák, A. (Eds.), Teaching foreign languages to adults (p. 24-29). Nitra: UKF.

COULMAS, F. (2013). Sociolinguistics: The Study of Speakers' Choices. Cambridge: Cambridge University Press.

Available

at:

https://books.google.sk/books?id=1oDRAwAAQBAJ\&printsec=frontcover\&hl=sk\&source=gbs_ge_su mmary_r\&cad $=0 \# \mathrm{v}=$ onepage $\& \mathrm{q} \& \mathrm{f}=$ false.

ČORNANIČOVÁ, R. (1998). Edukácia seniorov. Vznik, rozvoj, podnety pre geragogiku. Bratislava: UK.

GARDNER, H. (1983). Howard Gardner's multiple intelligences. (Frames of mind). Available at: http://businessballs.com/howardgardnermultipleintelligences.htm

GROFČÍIKOVÁ, S. (2011). Problematika učebných štýlov žiakov. In Vybrané kapitoly z didaktiky pedagogiky a sociálnej pedagogiky (p. 98-127). Nitra: UKF.

HARMER, J. (2007). The Practice of English Language Teaching. Harlow: Pearson Education, Ltd. Longmann.

HATÁR, C. (2014a). Geragogika. Vybrané kapitoly z teórie a metodiky edukácie seniorov. Nitra: UKF.

HATÁR, C. (2014b). Kvalita života inštitucionalizovaných seniorov v edukačnom kontexte. Nitra: UKF.

Klúčové kompetencie pre celoživotné vzdelávanie - európsky referenčný rámec. Available at: http://nuczv.sk/vzdelavanie-dospelych/wp-content/uploads/2015/05/ERR-KK_SK.pdf

KRASHEN, S. D. (1982). Principles and Practice in Second Language Acquisition. Oxford: Pergamon Press.

LIGHTBOWN, P. M. \& SPADA, N. (1997). Ako sa učíme jazyky. Bratislava: SAP.

MALÍKOVÁ, M. (2000). Kritický vek pre osvojovanie si cudzích jazykov. In Pongó, Š. \& Pokrivčák, A. (Eds.), Teaching foreign languages to adults (p. 15-18). Nitra: UKF.

MATULČ́́K, J. (2004). Teórie výchovy a vzdelávania dospelých v zahraničí. Bratislava: Gerlach Print.

Memorandum o celoživotnom vzdelávaní sa. Available at: http://www.minedu.sk/data/files/2607_2000_memorandum_o_celozivotnom_vzdelavani.pdf

MITTERLECHNER, Ch. (2012). Staroba neznamená koniec. In Socioterapia, 2(2), 8-10. Available at: http://www.socioterapia.info/wp-content/uploads/2011/04/Socioterapia_4_2012.pdf

Národný program aktívneho starnutia na roky 2014 - 2020. Available at:

https://lt.justice.gov.sk/Attachment/NPAS\%20vlastn\%C3\%BD\%20materi\%C3\%A1l.pdf?instEID=-

1\&attEID=58655\&docEID=325565\&matEID=

6548\&langEID=1\&tStamp $=20130823122420050$

Národný program ochrany starších l'udí. Available at: http://www.er2012.gov.sk/data/att/5578_subor.pdf

Národný program výchovy a vzdelávania vSlovenskej republike. Available at: http://www.cpk.sk/web/dokumenty/npvv.pdf

PETTY, G. (2002). 25 Ways for Teaching Without Talking. Available at: http://www.geoffpetty.com/activelearning.html 
PETŘKOVÁ, A. \& ČORNANIČOVÁ, R. (2004). Gerontagogika. Úvod do teorie a praxe edukace seniorů. Olomouc: UP.

POKRIVČÁKOVÁ, S. (2013). Applied Linguistics Research of Bilingualism and its Incentives for Foreign Language Pedagogy. Journal of Language and Cultural Education, 1(1), 51-62.

POKRIVČÁKOVÁ, S. (2014). Code-switching ako lingvodidaktický fenomén. X-Linguae, 7(2), 61-74.

PORUBSKÁ, G. \& ĎURDIAK, L. (2005). Manažment vzdelávania dospelých. Nitra: SlovDidac.

PRUSÁKOVÁ, V. (2010). Teoretické východiská analýzy vzdelávacích potrieb dospelých. In Prusáková, V. et al., Analýza vzdelávacích potrieb dospelých. Teoretické východiská (p. 13-44). Banská Bystrica: UMB.

PRŮCHA, J. (2014). Andragogický výzkum. Praha: Grada.

REID, J. M. (1998). Understanding Learning Styles in the Second Language Classroom. Upper Saddle River, NJ: Prentice Hall Regents.

REPKOVÁ, K. (2012). Dobrovol'níctvo v kontexte aktívneho starnutia: konceptuálna evolúcia a pretrvávajúce stereotypy. Rodina a práca, 4, 46.

RIDING, R. \& RAYNER, S. (2009). Cognitive Styles and Learning Strategies. London: David Fulton Publish.

SCHLEPPEGRELL, M. (1987). The Older Language Learner. ERIC Clearinghouse on Languages and Linguistics Washington DC. Identifier: ED287313.

SPOLSKY, B. (1998). Sociolinguistics. Oxford: Oxford University Press.

Stratégia celoživotného vzdelávania a celoživotného poradenstva do roku 2015. Vzdelávanie dospelých, 12(1), 7-20.

Stratégia celoživotného vzdelávania 2011. Available at: http://www.minedu.sk/data/files/1899.pdf

Štatút Univerzity tretieho veku (5/2011). Nitra: UKF.

ŠVEC, Š. (2008). Anglicko-slovenský lexikón pedagogiky a andragogiky. Bratislava: Iris.

ŠVEC, Š. et al. (2002). Jazyk vied o výchove. Bratislava: Gerlach Print.

ŠVEC, Š. et al. (1998). Metodológia vied o výchove. Kvantitatívno-scientistické a kvalitatívno-humanitné prístupy. Bratislava: Iris.

The Madrid International Plan of Action on Ageing. Guiding Framework and Toolkit for Practitioners\&Policy Makers. Available at: http://undesadspd.org/LinkClick.aspx?fileticket=8iGbix5_6gs\%3D\&tabid=502

TILESTON, D. W. (2004). What Every Teacher Should Know About Learning. Memory, and the Brain. California: Corwin Press.

TKÁČIKOVÁ, M. (2000). Basic Principles of Teaching Foreign Language to Adults. In Pongó, Š. \& Pokrivčák, A. (Eds.), Teaching foreign languages to adults (p. 24-29). Nitra: UKF.

TÓTHOVÁ, M. (2010). Mozog - reč - učenie. Východiská a podstata mozgovokompatibilného učenia $v$ neurodidaktickom kontexte. Nitra: UKF.

TUREK, I. (2003). Ako sa naučit' učit'. Prešov: MPC.

VÁGNEROVÁ, M. (2000). Vývojová psychologie. Praha: Portál.

VETEŠKA, J. \& TURECKIOVÁ, M. (2008). Kompetence ve vzdělávání. Praha: Grada.

ZAIDI, A. et al. (2013). Active Ageing Index 2012. Concept, Methodology and Final Results. Vienna: ECV. Available at: http://www1.unece.org/stat/platform/ download/attachments/76287849/Methodology-Paper\%20Final.pdf?

version=1\&modificationDate=1393836329990\&api=v2

Zákon č. 568/2009 Z. z. o celoživotnom vzdelávaní v znení neskorších predpisov. Available at: http://www.minedu.sk/data/att/8688.pdf

Zákon č. 448/2008 Z. z. o sociálnych službách v znení neskorších predpisov. Available at: http://www.employment.gov.sk/files/slovensky/uvod/

legislativa/socialna-pomoc-podpora/448-2008.pdf

Zákon č. 245/2008 Z. z. o výchove a vzdelávaní v znení neskorších predpisov. Available at: www.minedu.sk/data/att/8684.pdf 


\section{Contacts}

doc. PaedDr. Ctibor Határ, PhD.

Department of Pedagogy, Faculty of Education,

Constantine the Philosopher University in Nitra

Dražovská 4, 94974 Nitra, Slovakia

chatar@ukf.sk

PaedDr. Soňa Grofčíková, PhD.

Department of Pedagogy, Faculty of Education,

Constantine the Philosopher University in Nitra

Dražovská 4, 94974 Nitra, Slovakia

sgrofcikova@ukf.sk 